Supporting Information

\title{
A Systems Approach to Assess Trade Dependencies in U.S. Food-Energy-Water Nexus
}

\author{
Nemi Vora ${ }^{1,2 *}$, Brian D. Fath ${ }^{2,3}$, Vikas Khanna ${ }^{1}$ \\ ${ }^{1}$ Department of Civil and Environmental Engineering, University of Pittsburgh, 3700 O'Hara \\ Street, 742 Benedum Hall, Pittsburgh, Pennsylvania 15261, United States \\ ${ }^{2}$ Advanced Systems Analysis Program, International Institute for Applied Systems Analysis \\ (IIASA), Schlossplatz 1, A-2361 Laxenburg, Austria. \\ ${ }^{3}$ Department of Biological Sciences, Towson University, 8000 York Road, Towson, Maryland, \\ 21252, United States
}

Corresponding authors: bfath@towson.edu and khannav@pitt.edu

\section{Number of Pages: 14}

Number of Figures: 3

Number of tables: 8

\section{TABLE OF CONTENTS}

S1. Methodology framework ....................................................................................... 2

S2. Freight Analysis Framework (FAF) data.................................................................... 3

S2.1. Tracing origin of production in trade datasets. ........................................................ 3

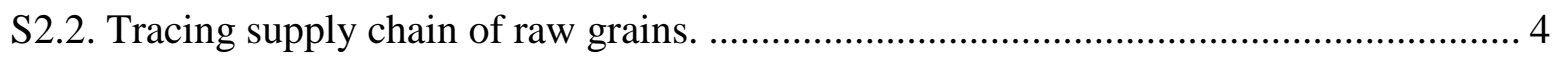

S3. Ground water withdrawal intensities for irrigation. ................................................ 5

S4. Derivation of PMI Measure .................................................................................... 5

S4.1 An example of flow distribution in null model .................................................... 6

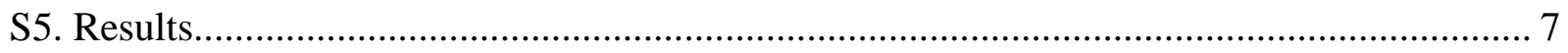

S5.1. Degree and Strength Distribution Comparison...................................................... 9

S5.2. Comparison with Social Network Measures .................................................. 12

S5.2. Code for PMI measure ............................................................................... 13 


\section{S1. Methodology framework}

Table S1. Methodological framework for building domestic grains and feed crops trade and associated irrigation impact matrices*

\begin{tabular}{|c|c|c|c|c|}
\hline No & $\begin{array}{l}\text { System } \\
\text { component }\end{array}$ & $\begin{array}{l}\text { Data sources } \\
\text { (year of analysis) }\end{array}$ & Ref. & Methodology \\
\hline \multirow[t]{3}{*}{1} & \multirow{3}{*}{$\begin{array}{l}\text { Interstate } \\
\text { grains and } \\
\text { animal feed } \\
\text { transfer data } \\
\text { (Mass flux in } \\
\text { US tons) }\end{array}$} & $\begin{array}{l}\text { Freight analysis } \\
\text { framework (2012) }\end{array}$ & 2 & \multirow{3}{*}{$\begin{array}{l}\text { - Disaggregated trade data based on } \\
\text { mass fractions of irrigated grains and } \\
\text { animal feed produced in each state. } \\
\text { - Assume a state has the same } \\
\text { percentage of irrigated crop transfers } \\
\text { as irrigated production. } \\
\text { - Irrigated production data for each crop } \\
\text { are obtained from Farm and Ranch } \\
\text { Irrigation Survey (FRIS-2013) Table } \\
\text { 35. } \\
\text { Data for corn, wheat, rice, sorghum, } \\
\text { alfalfa hay, hay, and corn silage were } \\
\text { provided in FRIS-2013. } \\
\text { - Irrigation data for rye and oats are not } \\
\text { separately published and instead } \\
\text { published under "other small grains" } \\
\text { category. The values are combined } \\
\text { with crop specific yields from NASS. } \\
\text { Data for barley was last published in } \\
\text { 2008 survey and is used for the study. }\end{array}$} \\
\hline & & $\begin{array}{l}\text { Farm and Ranch } \\
\text { Irrigation Survey } \\
\text { (FRIS) (2013) }\end{array}$ & 3 & \\
\hline & & $\begin{array}{l}\text { USDA census data } \\
\text { for production ( } 2012 \\
\text { or nearest year } \\
\text { available) }\end{array}$ & 4 & \\
\hline \multirow[t]{2}{*}{2} & \multirow[t]{2}{*}{$\begin{array}{l}\text { Irrigation } \\
\text { intensities } \\
\left(\mathrm{m}^{3} / \text { ton }\right)\end{array}$} & $\begin{array}{l}\text { Farm and Ranch } \\
\text { Irrigation Survey } \\
\text { (FRIS) }(2013,2008)\end{array}$ & 3 & \multirow[b]{2}{*}{$\begin{array}{l}\text { - Water application statistics for crops } \\
\text { and for specific states (acre-ft/acre) } \\
\text { are combined with irrigated yields } \\
\text { (tons/acre) to obtain irrigation water } \\
\text { applied per ton }\left(\mathrm{m}^{3} / \text { ton) of crop. }\right. \\
\text { - All values are obtained from FRIS } \\
\text { Table } 36 \text {. We follow the same method } \\
\text { for each commodity as described for } \\
\text { irrigated production fraction (Table } \\
\text { S1, No 1) for obtaining individual } \\
\text { water application intensities. } \\
\text { We use state level production } \\
\text { weighted average water application } \\
\text { intensities to combine items into } \\
\text { grouped trade data. }\end{array}$} \\
\hline & & $\begin{array}{l}\text { USDA census data } \\
\text { for yields ( } 2012 \text { or } \\
\text { nearest year } \\
\text { available) }\end{array}$ & 4 & \\
\hline
\end{tabular}




\begin{tabular}{|c|c|c|c|}
\hline $\begin{array}{l}\text { Irrigation } \\
\text { pumping } \\
\text { energy and } \\
\text { emissions } \\
\text { intensities } \\
\left(\mathrm{kg} \mathrm{CO} \mathrm{CO}_{2} \mathrm{e} \mathrm{m}^{3}\right) \\
\text { and }\left(\mathrm{MJ} / \mathrm{m}^{3}\right)\end{array}$ & $\begin{array}{l}\text { Farm and Ranch } \\
\text { Irrigation Survey } \\
\text { (FRIS) (2013) } \\
\text { U.S. Energy } \\
\text { Information } \\
\text { Administration } \\
\text { (EIA) (2012) } \\
\text { US Life cycle } \\
\text { inventory database } \\
\text { (USLCI) }\end{array}$ & 5 & $\begin{array}{l}\text { - FRIS Table } 12 \text { provides cost of } \\
\text { pumping for each state based on fuel } \\
\text { type (electricity, natural gas, LPG, } \\
\text { Propane, Butane, Diesel, and } \\
\text { Gasoline), combined with fuel prices } \\
\text { from EIA. } \\
\text { - The states with undisclosed fuel } \\
\text { expenses data were estimated based } \\
\text { on total irrigation energy expenses } \\
\text { divided proportionally between } \\
\text { farms employing a particular fuel } \\
\text { source for pumping. } \\
\text { Used USLCI and SimaPro to } \\
\text { estimate 100-year global warming } \\
\text { potential and cumulative energy } \\
\text { demand and combined with } \\
\text { irrigation water intensities to arrive } \\
\text { at GHG emissions per cubic meter of } \\
\text { water withdrawn. }\end{array}$ \\
\hline
\end{tabular}

* The methodology adopted from Vora, N.; Shah, A.; Bilec, M. M.; Khanna, V., Food-EnergyWater Nexus: Quantifying Embodied Energy and GHG emissions from Irrigation through Virtual Water Transfers in Food Trade. ACS Sustainable Chemistry \& Engineering 2017. Copyright (2017) ACS Sustainable Chemistry \& Engineering

S2. Freight Analysis Framework (FAF) data

Table S2. Food items included in Freight Analysis Framework SCTG (Standard Classification of Transported Goods system) groups and items considered in the study.

\begin{tabular}{|c|c|c|c|}
\hline $\begin{array}{l}\text { SCTG } \\
\text { code }\end{array}$ & $\begin{array}{l}\text { Commodity } \\
\text { name }\end{array}$ & Includes (but not limited to) & Considered \\
\hline 02 & $\begin{array}{l}\text { Cereal } \\
\text { Grains and } \\
\text { seeds }\end{array}$ & $\begin{array}{l}\text { Wheat, field corn, rye, barley, } \\
\text { oats, grain sorghum, other } \\
\text { cereal grains (including rice) }\end{array}$ & $\begin{array}{l}\text { Wheat, rice, barley, corn (not diverted } \\
\text { to ethanol), rye, oats, sorghum }\end{array}$ \\
\hline 04 & $\begin{array}{l}\text { Animal feed } \\
\text { and products } \\
\text { of animal } \\
\text { origin }\end{array}$ & $\begin{array}{l}\text { Cereal straws or husks and } \\
\text { forage, residues and wastes } \\
\text { from food industries used in } \\
\text { animal feed, and other } \\
\text { products of animal origin not } \\
\text { elsewhere classified. }\end{array}$ & $\begin{array}{l}\text { Corn silage, sorghum silage, alfalfa } \\
\text { hay, hay }\end{array}$ \\
\hline
\end{tabular}

S2.1. Tracing origin of production in trade datasets.

The Freight Analysis Framework (FAF) data are derived from a shipper-based commodity flow 
survey (CFS). ${ }^{7}$ CFS surveys selected shipper establishments in a given quarter and extrapolates to represent interstate and within-state shipments across the U.S. for the entire year.

Ideally, the respondent would provide information related to the entire trip of a shipment, but a few may not explicitly specify internal hubs and stops for the shipment or the respondent would only be responsible for part of the route. Therefore, the trade data may not be able to distinguish hubs/ warehouses from intermediate states vs. actual origin and destinations of shipment. This may lead to double counting in trade statistics and potentially inaccurate estimates of locationbased consumption impacts. For instance, rice produced in Arkansas may travel to New York through Ohio, where only the shipment from Ohio to New York is recorded, thereby inaccurately attributing environmental impacts of rice consumed in New York to Ohio's production. In actual case, Ohio may have only served as a shipment hub and no rice was produced in Ohio. This is a common issue in consumption-based accounting through food trade and usually solved through use of some form of origin tracing algorithms. ${ }^{8-10}$

FAF data provide trade for specific aggregated commodity groups based on Standard Classification of Transported Goods (SCTG) classification system (e.g. shipment of cereal grains). To reconcile trade with item-based impacts, we disaggregate commodity groups based on grains production (e.g. production of rice in Arkansas). Therefore, if a state does not produce a given crop (e.g. Ohio), it will not be sending out that commodity in the resulting trade matrix. Similar production-based origin tracing method have been used in USDA estimates ${ }^{11}$ of origin of agriculture exports as well as other trade studies. ${ }^{12}$ Therefore, our method ensures that we do not incorrectly allocate production to non-producing states. However, in some cases, re-exports may come from production states as well. For example, Tennessee produces rice but imports some fraction from Arkansas and ships certain amount to New York. Therefore, the New York shipment from Tennessee may contain some of the re-exports from Arkansas along with local production from Tennessee. Additionally, in inter-regional trade, a state may be shipping some of the grains from previous year's stock, which is not usually considered in the mass-balance equations used in the origin tracing algorithms. To our knowledge, state level data on supply and demand is not available for all food commodities and requires building a comprehensive supply chains from bottom up such as demonstrated by Smith et al. for corn in the U.S. ${ }^{13}$ This is an area of future work for reconciling subnational trade datasets.

S2.2. Tracing supply chain of raw grains.

In this work, we assume the origin and destination to be production and consumption states respectively. With origin-tracing methods specified above, one can trace place of actual production. However, due to unavailability of complete supply chain data (raw grains transferred to milled products, and ultimately consumed), it is a common practice to assume processed products have locally sourced raw ingredients to avoid double counting. ${ }^{1,14-16}$ This poses a risk of underestimating consumption flows in specific states. For example, if New York mills rice sourced from Arkansas, and does not produce the rice itself, that flow will not be accounted for in production-oriented approach discussed in S2.1. Therefore, if the milled rice was subsequently sent to Pennsylvania from New York, the consumption of rice in Pennsylvania through trade would be underestimated. By only focusing on raw grains and feed in the study, we account for the first step of supply chain. Therefore, we do not distinguish the place of 
destination as place of final consumption. However, our results of dependence still hold true as a disruption in production state will cause impacts to both place of final consumption and industries and services reliant on middle-hubs in the chain.

S3. Ground water withdrawal intensities for irrigation.

We estimate water withdrawal intensities (WWI) by combining Farm and Ranch Irrigation Survey $(\text { FRIS })^{3}$ applied water estimates with irrigated yield data. FRIS provides average application rate specific to crops, weighted by type of irrigation system for each state in acre-ft per acre. Our primary data source for irrigated yields is also from FRIS $^{3}$ with missing information supplemented from agriculture census database. ${ }^{17}$ To estimate groundwater specific WWI depicted in figure 3 in the manuscript, we multiply the WWI with state-specific fraction of groundwater withdrawals. The state specific fraction of withdrawals attributed to groundwater is calculated from USGS irrigation withdrawals data for 2010.

$$
\begin{aligned}
& \text { WWI }\left(\mathrm{m}^{3} / \text { ton }\right) \\
& =\frac{\text { water application rate }\left(\mathrm{m}^{3} / \text { acre }\right) \times \text { groundwater irrigation withdrawals }}{\text { crop yield }(\text { ton } / \text { acre }) \times \text { total irrigation withdrawals }}
\end{aligned}
$$

\section{S4. Derivation of PMI Measure}

We analyze state-wise trade dependencies through pointwise mutual information (PMI) measure. Originally from information theory, the PMI concept is adopted from ecological network analysis. ${ }^{18}$ Information-based ecological network analysis is based on concepts from information theory, graph theory, probability, and statistics. It is rooted in understanding what is missing ${ }^{18}$ and embodies the principle that reduced indeterminacy of the system is a measure of the information gain. Mathematically, it is represented using Shannon's entropy for a system's macro-state $(H)$ and its relation to the probability distribution of possible microstates $(p)^{19}$ (also similar to Boltzmann's equation of entropy). The equation can be seen as quantifying the non-occurrence (indicated by the - ve sign) of an event (with probability $p$ of occurring). ${ }^{18}$

$$
H=-k \log (p)
$$

Here, $k$ is a scalar constant. PMI measures probability of two events occurring together. To understand the relationship between dyads $i$ and $j$, eq. 1 can be re-written as,

$$
H_{i j}=-k \log \left(p_{i j}\right)
$$

Here, $H_{i j}$ represents indeterminacy of a random event $i$ and $j$ occurring together. $p_{i j}$ is the probability of $i$ and $j$ co-occurring. The log base for the analysis is 2, giving the information unit "Shannon".

Conversely, if events $i$ and $j$ are completely independent of each other, knowing one would not reduce indeterminacy of other's occurrence. Therefore, it is assumed that a situation where both events are independent of each other represents a state of maximal indeterminacy (eq. S6). ${ }^{18}$ If events $i$ and $j$ are independent of each other, then the probability of their co-occurrence is given by 
their marginal probability of occurrences. Marginal probability of occurrence for event $i$ is $p_{i \text {. }}$ (eq. $\mathrm{S} 4)$ and for $j$ is given as $p_{. j}$ (eq. S5)

$$
\begin{aligned}
& p_{i .}=\sum_{j} p_{i j} \\
& p_{. j}=\sum_{i} p_{i j}
\end{aligned}
$$

We re-write eq. S3 for maximal indeterminacy $H_{i j}^{*}$ as,

$$
H_{i j}^{*}=-k \log \left(p_{i .} p_{. j}\right)
$$

The maximal indeterminacy is also referred to as the null model in the main manuscript. Comparing a state of maximal indeterminacy with observed flow would yield additional information that is present in the system. The difference between maximal indeterminacy and actual indeterminacy can be described as the measure of mutual information between $i$ and $j^{20}$, termed as pointwise mutual (PMI) information

$$
P M I_{i j}=H_{i j}^{*}-H_{i j}=-k \log \left(p_{i .} p_{. j}\right)-\left(-k \log \left(p_{i j}\right)\right)=k \log \frac{p_{i j}}{p_{i . p_{. j}}}
$$

\section{S4.1 An example of flow distribution in null model}

To further explain what we mean by trade equitability, we present a toy model of trade $(\mathrm{T})$ in Table 1 and associated null model (M) in table 2 in the SI. The $\mathbf{M}_{\mathrm{i}}$. and $\mathrm{M}_{\mathrm{j}}$ represent sum of columns and rows of $\mathrm{M}$ respectively which correspond to the Ti. and T.j for matrix T. From Table 3, it can be seen that the proportion of outgoing mass from a state to other states is the same across all states. In table 4, the proportion of incoming mass to a given state from other states is the same across the board. The trade direction is from $\mathrm{i}$ (row) to $\mathrm{j}$ (column). In this case, B consumes the most (22), and therefore receives highest portion (47\% of their outgoing flow) from each state. $\mathrm{C}$ exports the most (36), and therefore each state receives highest portion (77\% of all incoming flow) from $\mathrm{C}$.

Table S3. Example of a hypothetical trade matrix (T)

\begin{tabular}{|l|l|l|l|l|}
\hline T & A & B & C & Ti. \\
\hline A & 0 & 6 & 1 & $\mathbf{7}$ \\
\hline B & 0 & 4 & 0 & $\mathbf{4}$ \\
\hline C & 12 & 12 & 12 & $\mathbf{3 6}$ \\
\hline T.j & $\mathbf{1 2}$ & $\mathbf{2 2}$ & $\mathbf{1 3}$ & $\mathbf{4 7}$ \\
\hline
\end{tabular}


Table S4. Calculated null model matrix(M) for given trade

\begin{tabular}{|l|l|r|r|r|}
\hline & A & B & C & Mi. \\
\hline A & 1.79 & 3.28 & 1.94 & $\mathbf{7}$ \\
\hline B & 1.02 & 1.87 & 1.11 & $\mathbf{4}$ \\
\hline C & 9.19 & 16.85 & 9.96 & $\mathbf{3 6}$ \\
\hline M.j & $\mathbf{1 2}$ & $\mathbf{2 2}$ & $\mathbf{1 3}$ & $\mathbf{4 7}$ \\
\hline
\end{tabular}

Table S5. Outgoing flow distribution in null model $\left(T_{\mathrm{ij}} / \mathrm{T}_{\mathrm{i}}\right)$

\begin{tabular}{|l|c|r|r|}
\hline Fraction outgoing contribution & \multicolumn{1}{l|}{ A } & B & \multicolumn{1}{l|}{ C } \\
\hline A & $1.79 / 7=0.26$ & $3.28 / 7=0.47$ & $1.94 / 7=0.28$ \\
\hline B & $1.02 / 4=0.26$ & $1.87 / 4=0.47$ & $1.11 / 4=0.28$ \\
\hline C & $9.19 / 36=0.26$ & $16.85 / 36=0.47$ & $9.96 / 36=0.28$ \\
\hline
\end{tabular}

Table S6. Incoming flow distribution in null model $\left(T_{\mathrm{ij}} / T_{\mathrm{j}}\right)$

\begin{tabular}{|l|l|r|l|}
\hline Fraction incoming contribution & $\mathrm{A}$ & $\mathrm{B}$ & $\mathrm{C}$ \\
\hline $\mathrm{A}$ & $1.79 / 12=0.15$ & $3.28 / 22=0.15$ & $1.94 / 13=0.15$ \\
\hline $\mathrm{B}$ & $1.02 / 12=0.09$ & $1.87 / 22=0.09$ & $1.11 / 13=0.09$ \\
\hline $\mathrm{C}$ & $9.19 / 12=0.77$ & $16.85 / 22=0.77$ & $9.96 / 13=0.77$ \\
\hline
\end{tabular}

S5. Results

Table S7. Total flows in the network

\begin{tabular}{|l|r|r|}
\hline Networks & Cereal grains & Animal feed \\
\hline Irrigated food transfers (US tons) & $4.60 \mathrm{E}+08$ & $1.53 \mathrm{E}+08$ \\
\hline Virtual water transfers $\left(\mathrm{m}^{3}\right)$ & $1.35 \mathrm{E}+11$ & $3.09 \mathrm{E}+10$ \\
\hline
\end{tabular}




\begin{tabular}{|l|r|r|}
\hline Irrigation embodied energy transfers (MJ) & $5.46 \mathrm{E}+11$ & $8.69 \mathrm{E}+10$ \\
\hline $\begin{array}{l}\text { Irrigation embodied GHG emissions transfers } \\
\text { (kg CO} 2 \text { equivalent) }\end{array}$ & $3.66 \mathrm{E}+10$ & $5.78 \mathrm{E}+09$ \\
\hline
\end{tabular}

Table S8. Texas's importing partners ranked by their PMI in a descending order, compared with actual food imports and respective rank. Positive PMI indicates higher than expected dependency and negative PMI indicates lower than expected dependency.

\begin{tabular}{|c|c|c|c|c|}
\hline $\begin{array}{l}\text { Incoming } \\
\text { flow }\end{array}$ & PMI & \begin{tabular}{|l|} 
PMI \\
Rank \\
\end{tabular} & $\begin{array}{l}\text { Volume } \\
\text { (US tons) }\end{array}$ & $\begin{array}{l}\text { Volume } \\
\text { Rank } \\
\end{array}$ \\
\hline Texas & 3.31 & 1 & $3.23 \mathrm{E}+07$ & 1 \\
\hline Kansas & 1.61 & 2 & $1.77 \mathrm{E}+07$ & 2 \\
\hline Oklahoma & 1.10 & 3 & $2.76 \mathrm{E}+06$ & 3 \\
\hline Louisiana & 0.23 & 4 & $9.38 \mathrm{E}+05$ & 5 \\
\hline New Mexico & -0.05 & 5 & $1.19 \mathrm{E}+05$ & 11 \\
\hline Indiana & -1.59 & 6 & $6.60 \mathrm{E}+05$ & 6 \\
\hline Missouri & -2.17 & 7 & $4.06 \mathrm{E}+05$ & 7 \\
\hline Tennessee & -2.51 & 8 & $5.99 \mathrm{E}+04$ & 16 \\
\hline Nebraska & -2.76 & 9 & $1.37 \mathrm{E}+06$ & 4 \\
\hline Arizona & -2.81 & 10 & $6.01 \mathrm{E}+04$ & 15 \\
\hline Iowa & -3.48 & 11 & $3.66 \mathrm{E}+05$ & 8 \\
\hline North Dakota & -3.56 & 12 & $6.99 \mathrm{E}+04$ & 14 \\
\hline Arkansas & -3.62 & 13 & $1.07 \mathrm{E}+05$ & 12 \\
\hline Utah & -3.99 & 14 & $1.87 \mathrm{E}+04$ & 20 \\
\hline Minnesota & -4.20 & 15 & $2.24 \mathrm{E}+05$ & 9 \\
\hline South Dakota & -4.25 & 16 & $9.94 \mathrm{E}+04$ & 13 \\
\hline Pennsylvania & -4.29 & 17 & $5.86 \mathrm{E}+03$ & 23 \\
\hline Illinois & -4.44 & 18 & $1.88 \mathrm{E}+05$ & 10 \\
\hline Georgia & -4.63 & 19 & $2.07 \mathrm{E}+04$ & 19 \\
\hline Colorado & -5.49 & 20 & $5.17 \mathrm{E}+04$ & 17 \\
\hline Ohio & -5.57 & 21 & $1.72 \mathrm{E}+04$ & 22 \\
\hline Wisconsin & -5.91 & 22 & $2.42 \mathrm{E}+04$ & 18 \\
\hline New Jersey & -6.22 & 23 & $3.60 \mathrm{E}+02$ & 28 \\
\hline California & -7.04 & 24 & $1.86 \mathrm{E}+04$ & 21 \\
\hline Michigan & -7.91 & 25 & $4.91 \mathrm{E}+03$ & 24 \\
\hline Kentucky & -8.30 & 26 & $5.86 \mathrm{E}+02$ & 27 \\
\hline Mississippi & -8.45 & 27 & $1.76 \mathrm{E}+03$ & 25 \\
\hline Florida & -9.65 & 28 & $9.67 \mathrm{E}+02$ & 26 \\
\hline $\begin{array}{l}\text { South } \\
\text { Carolina }\end{array}$ & -11.46 & 29 & $4.86 \mathrm{E}+01$ & 30 \\
\hline
\end{tabular}




\begin{tabular}{|l|r|r|r|r|}
\hline Montana & -12.64 & 30 & $1.18 \mathrm{E}+02$ & 29 \\
\hline Virginia & -15.70 & 31 & $2.61 \mathrm{E}+00$ & 32 \\
\hline Alabama & -15.99 & 32 & $4.08 \mathrm{E}+00$ & 31 \\
\hline New York & -18.04 & 33 & $5.90 \mathrm{E}-01$ & 33 \\
\hline Connecticut & -19.24 & 34 & $1.60 \mathrm{E}-03$ & 34 \\
\hline
\end{tabular}

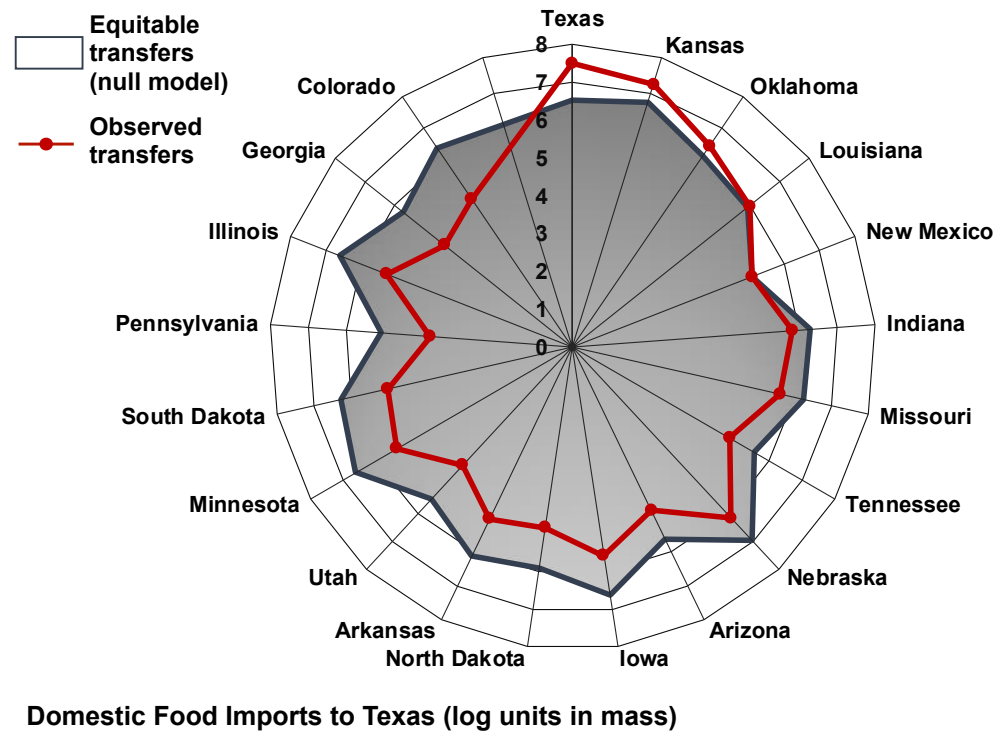

Figure S1. Comparison of expected food incoming transfers (shaded grey area) and observed transfers for top ten partners for Texas. The values are represented on a log scale and units are in US tons. The visualization is useful in comparing which states are exporting close to their null model (Louisiana, New Mexico) and which are over/under transferring.

\section{S5.1. Degree and strength distribution comparison}

Degree and strength are primary descriptive network statistics. Degree calculates number of connections and depending on the direction of the connection, it can be separated into in-degree (incoming connections) or out-degree (out-going connection) of a network. Strength of a network represents weights in the network, and similar to degrees are subdivided into in-coming strength and out-going strengths. Figure S2 compares degree and strength distribution for observed and expected network flows and connections. The black circles represent observed transfers and connections, the red cross represents the expected flow. As seen from the strength distributions of each network $\left(\mathrm{s}_{\text {in }} / \mathrm{s}_{\text {out }}\right)$, the total flow remains the same in the null model and observed flow. However, individual links are re-wired to create an equitable structure, which can be shown through degree connections. The null model's degree distribution $\left(\mathrm{k}_{\text {in }} / \mathrm{k}_{\text {out }}\right)$ exhibits a fully connected topology denoted by all states having the same indegrees: 45 and out-degrees 51 or 0 . The 0 out-going degrees are for states with no outgoing flow of grains or feed crops and consists of Alaska, Maine, New Hampshire, Rhode Island, Vermont, Washington DC. As the difference in each network is due to change in weights, the degree distribution remains same for each layer. 

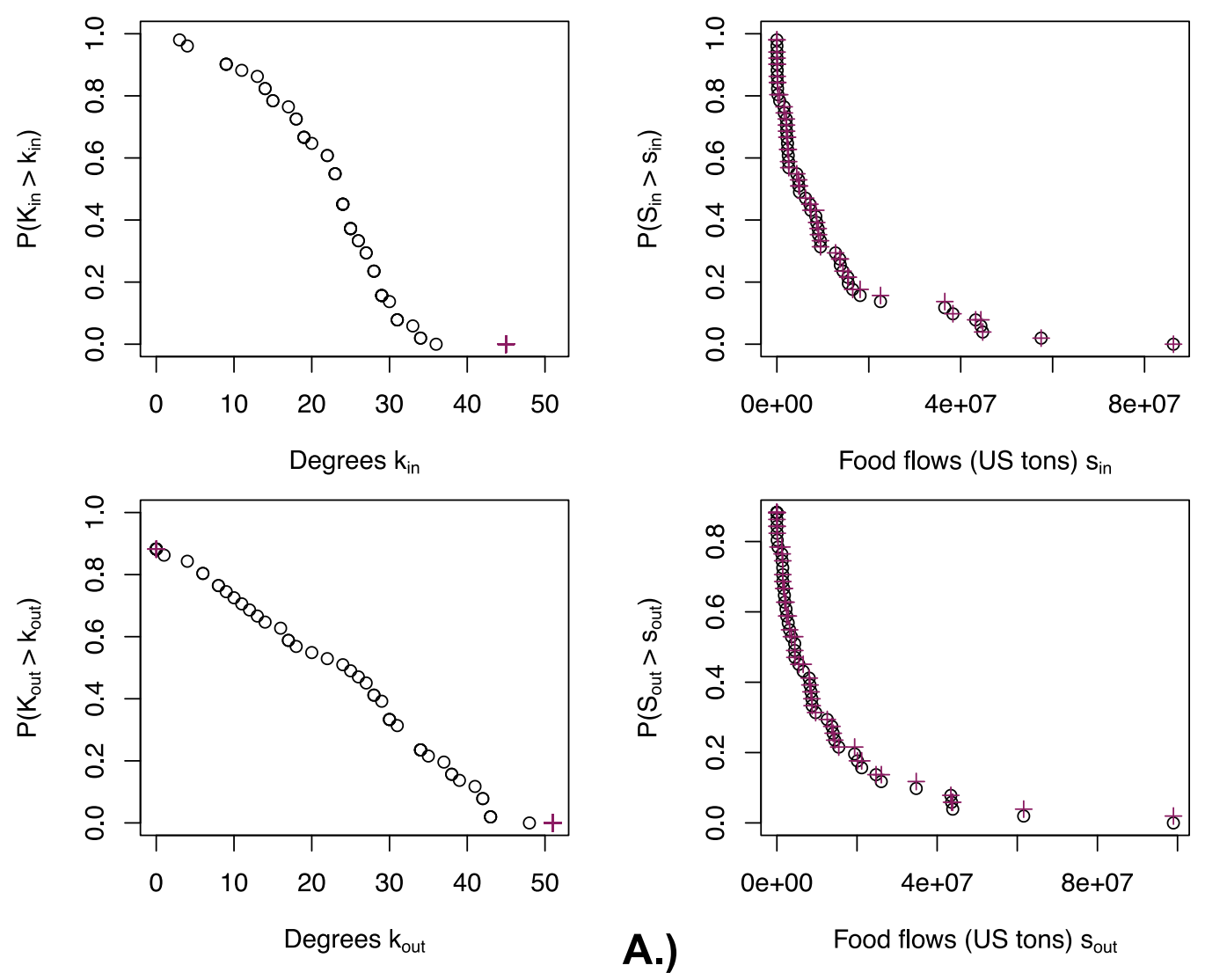

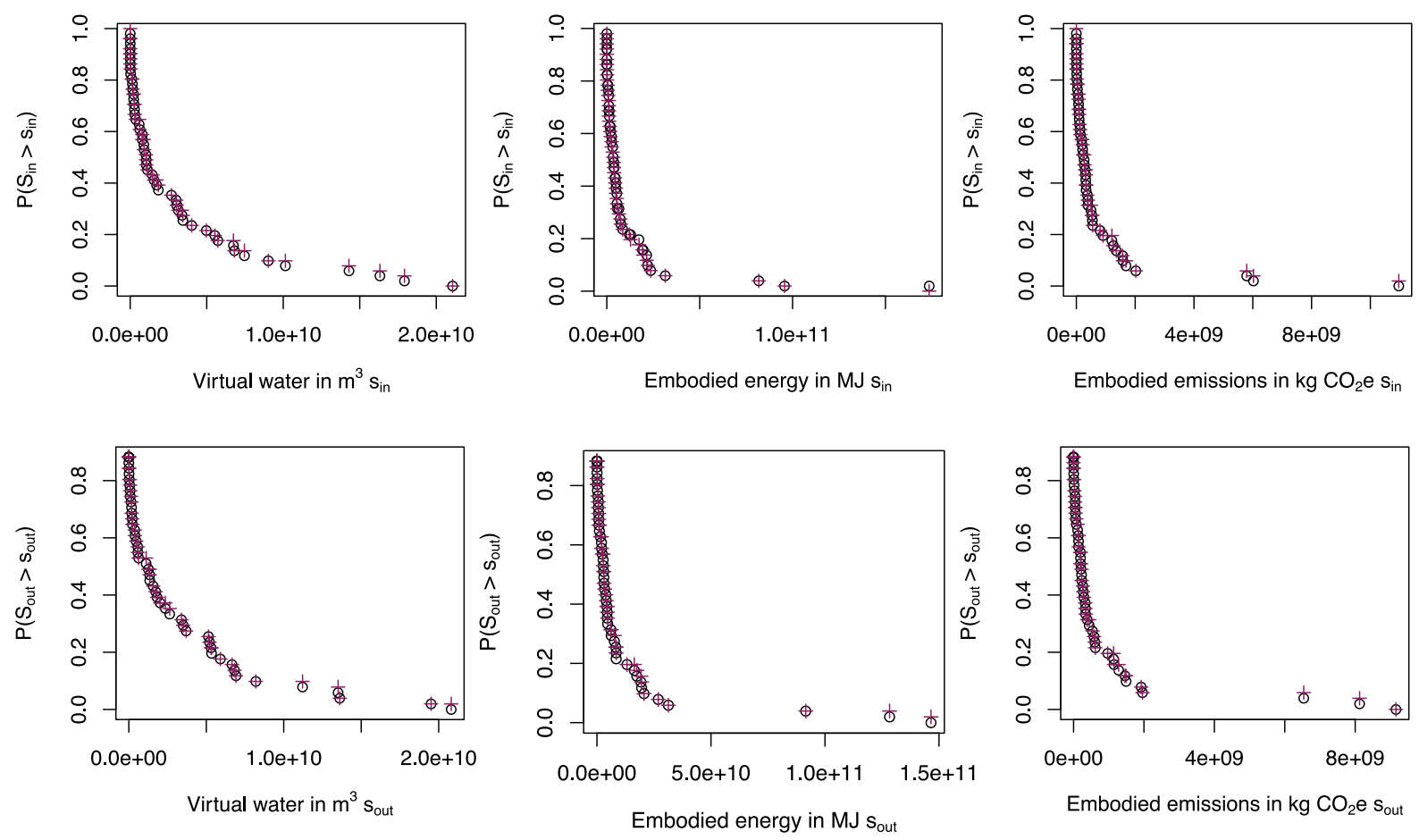

B.)

Figure S2. Complementary cumulative distributions of in $(/$ out $)$ degree $\left(\mathrm{k}_{\mathrm{in}} / \mathrm{k}_{\text {out }}\right)$ and strength distribution ( $\mathrm{sin}_{\mathrm{in}} / \mathrm{s}_{\mathrm{sut}}$ ) of food flows (A) and strength distributions ( $\mathrm{sin}_{\mathrm{n}} / \mathrm{s}_{\mathrm{out}}$ ) of irrigation impact flows (B). The black circles represent observed transfers and connections, the red cross represents the expected flow. As the null model is formulated based on total incoming/outgoing strength constraints from each state, the strength distributions remain consistent for expected flow denoted by black circles and red crosses falling on the same line. The null model's degree distribution exhibits a fully connected topology denoted by all states having the same indegrees: 45 and outdegrees 51 or 0 . 

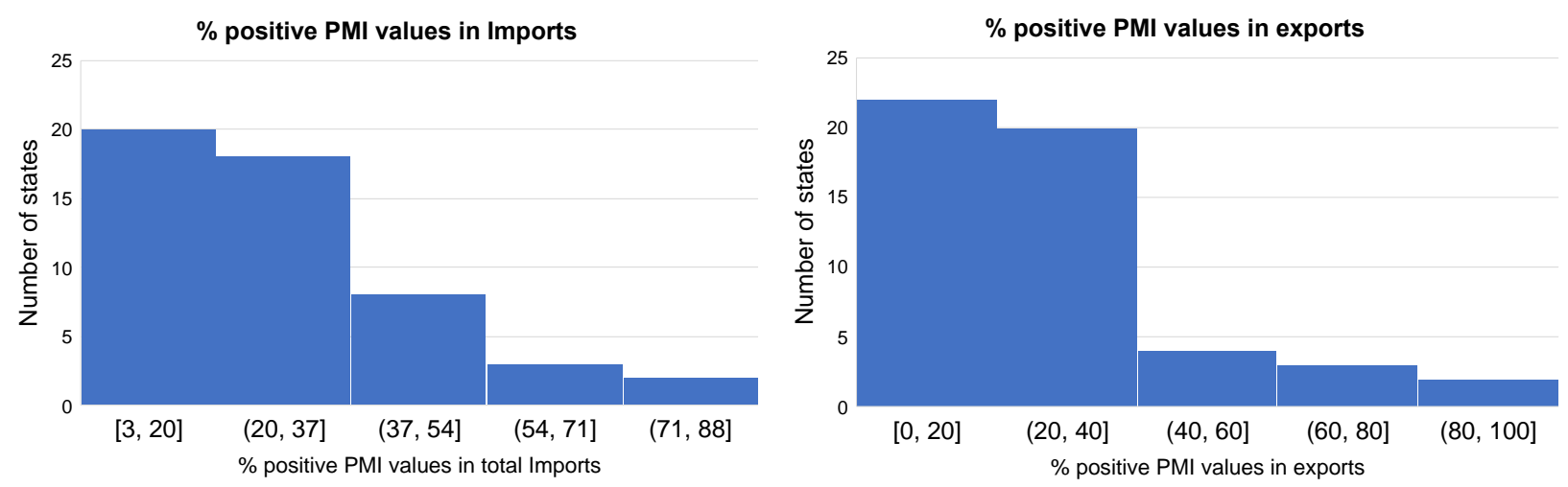

Figure S3. Presence of positive PMI values in import and export relations. Each histogram shows that majority of states have lower percentage of positive PMI values in their import and export connections. This indicates that states are highly reliant (based on mass flux) on a few states in their export and import connections, and therefore prone to vulnerability in those connections.

\section{S5.2. Comparison with social network measures}

Since we focus on Texas and its imports, we compare PMI ranking with the most relevant social network node-level measure: the degree centrality. We first provided the reasoning for degree centrality over other centrality measures for bilateral exchanges in Vora et al. ${ }^{1}$ citing that trade flows cannot be substituted as geodesic data (e.g. distance between two states). As this is a directed network (a network where direction of the flow matters), we compare in-degree centrality with PMI ranks for Texas' imports. The in-degree centrality measures the number of links directed into a node normalized by the maximum number of such links. Here, the input graph is a vector of dimension $[51 \times 1]$ since we are interested in 51 states exporting to Texas. The out-degree centrality measures the number of links directed out of the node and does not apply here (as we'd only get out-degrees for Texas). However, as seen from table S5, the in-degree centrality follows closely the rankings of volume. When we examine, Texas' exports as well, a separate vector of $[1 \times 51]$, we see states such as New Mexico, Arkansas, Tennessee show up. Here, in-degree centrality is not relevant, and we compare out-degree centrality. The centrality calculations are performed with the ORA software. ${ }^{18}$ Measures such as betweenness centrality are network level and would apply only if we were examining the entire $[51 \times 51]$ network. Additionally, the centrality rankings would be more insightful if they are compared against a random network of similar properties to check if the properties we examine are uniquely attributable to the network under study. If we include sufficient number of appropriate measures, we would get a complete picture of the network. The challenge with interdisciplinary approach is choosing such appropriate network measures that were originally developed for social or ecological networks and interpreting the results for trade analysis. The purpose here is to show the compactness of PMI in delivering information on importance of trade partner nodes from the network perspective while comparing against a random network (null model) while inherently accounting for flow direction, self-loops, and weights in the network in one measure. 
Table S9. Comparison of degree centrality with PMI

\begin{tabular}{|l|r|c|c|c|c|r|}
\hline State & $\begin{array}{l}\text { PMI } \\
\text { rank }\end{array}$ & $\begin{array}{l}\text { Import } \\
\text { volume } \\
\text { rank }\end{array}$ & $\begin{array}{l}\text { In-degree } \\
\text { centrality rank }\end{array}$ & $\begin{array}{l}\text { In-degree } \\
\text { centrality } \\
\text { (scaled) }\end{array}$ & $\begin{array}{l}\text { Out-degree } \\
\text { Out-degree } \\
\text { centrality rank }\end{array}$ & $\begin{array}{l}\text { centrality } \\
\text { (scaled) }\end{array}$ \\
\hline TX & 1 & 1 & 1 & $1.80 \mathrm{E}-02$ & 1 & $2.00 \mathrm{E}-02$ \\
\hline KS & 2 & 2 & 2 & $5.00 \mathrm{E}-03$ & 6 & $5.98 \mathrm{E}-05$ \\
\hline OK & 3 & 3 & 3 & $8.45 \mathrm{E}-04$ & 2 & $7.32 \mathrm{E}-05$ \\
\hline LA & 4 & 5 & 5 & $2.88 \mathrm{E}-04$ & 4 & $4.39 \mathrm{E}-04$ \\
\hline NM & 5 & 11 & 11 & $3.65 \mathrm{E}-05$ & 3 & $0.00 \mathrm{E}+00$ \\
\hline IN & 6 & 6 & 6 & $2.03 \mathrm{E}-04$ & 37 & $1.02 \mathrm{E}-05$ \\
\hline MO & 7 & 7 & 7 & $1.25 \mathrm{E}-04$ & 15 & $2.96 \mathrm{E}-05$ \\
\hline TN & 8 & 16 & 16 & $1.84 \mathrm{E}-05$ & 9 & $3.17 \mathrm{E}-06$ \\
\hline NE & 9 & 4 & 4 & $4.20 \mathrm{E}-04$ & 24 & $3.09 \mathrm{E}-05$ \\
\hline AZ & 10 & 15 & 15 & $1.84 \mathrm{E}-05$ & 13 & $0.00 \mathrm{E}+00$ \\
\hline IA & 11 & 8 & 8 & $1.12 \mathrm{E}-04$ & 8 & $6.74 \mathrm{E}-05$ \\
\hline ND & 12 & 14 & 14 & $2.15 \mathrm{E}-05$ & 42 & $0.00 \mathrm{E}+00$ \\
\hline AR & 13 & 12 & 12 & $3.29 \mathrm{E}-05$ & 5 & \\
\hline UT & 14 & 20 & 20 & $5.75 \mathrm{E}-06$ & 45 & \\
\hline
\end{tabular}

S5.2. Code for PMI measure

Contact authors Nemi Vora/ Brian Fath for the PMI implementation code.

References:

1. Vora, N.; Shah, A.; Bilec, M. M.; Khanna, V., Food-Energy-Water Nexus: Quantifying Embodied Energy and GHG emissions from Irrigation through Virtual Water Transfers in Food Trade. ACS Sustainable Chemistry \& Engineering 2017.

2. Hwang, H.-L.; Hargrove, S.; Chin, S.-M.; Wilson, D. W.; Davidson, D. Freight Analysis Framework Verson 4-Building the FAF4 Regional Database: Data Sources and Estimation Methodologies; Oak Ridge National Laboratory (ORNL), Oak Ridge, TN (United States): 2016. 3. USDA, Farm and Ranch Irrigation Survey. 2013.

4. USDA;, Census of Agriculture. 2012.

5. Energy Information Administration, U. S. Electric Power Monthly with Data for December 2013; US Energy Information Administration: 2014.

6. National Renewable Energy Laboratory, U.S. Life Cycle Inventory Database 2012.

7. Census Bureau, U. S.; Department of Transportation, U. S., Commodity Flow Survey. 2012.

8. Chapagain, A. K.; Hoekstra, A. Y., Virtual water flows between nations in relation to trade in livestock and livestock products. UNESCO-IHE Delft, The Netherlands: 2003.

9. Kissinger, M.; Rees, W. E., Importing terrestrial biocapacity: The US case and global implications. Land Use Policy 2010, 27 (2), 589-599. 
10. Kastner, T.; Kastner, M.; Nonhebel, S., Tracing distant environmental impacts of agricultural products from a consumer perspective. Ecological Economics 2011, 70 (6), 10321040 .

11. ERS, U. Estimating State Exports. https://www.ers.usda.gov/data-products/state-exportdata/documentation/\#Methodagproduction, accessed on 6-30-2019

12. Marston, L.; Konar, M., Drought impacts to water footprints and virtual water transfers of the Central Valley of California. Water Resources Research 2017, 53 (7), 5756-5773.

13. Smith, T. M.; Goodkind, A. L.; Kim, T.; Pelton, R. E.; Suh, K.; Schmitt, J., Subnational mobility and consumption-based environmental accounting of US corn in animal protein and ethanol supply chains. Proceedings of the National Academy of Sciences 2017, 114 (38), E7891E7899.

14. Marston, L.; Konar, M.; Cai, X.; Troy, T. J., Virtual groundwater transfers from overexploited aquifers in the United States. Proceedings of the National Academy of Sciences 2015, 112 (28), 8561-8566.

15. Dang, Q.; Lin, X.; Konar, M., Agricultural virtual water flows within the United States. Water Resources Research 2015, 51 (2), 973-986.

16. Hoekstra, A. Y.; Hung, P., Virtual water trade. A quantification of virtual water flows between nations in relation to international crop trade. Value of water research report series 2002, 11, 166.

17. Department of Agriculture, U. S., National Agricultural Statistics Service. 2012.

18. Ulanowicz, R. E.; Goerner, S. J.; Lietaer, B.; Gomez, R., Quantifying sustainability: resilience, efficiency and the return of information theory. Ecological complexity 2009, 6 (1), 2736.

19. Shannon, C. E., A mathematical theory of communication. Bell system technical journal 1948, 27 (3), 379-423.

20. Kharrazi, A.; Fath, B. D., Measuring global oil trade dependencies: An application of the point-wise mutual information method. Energy Policy 2016, 88, 271-277.

21. Carley, K. M.; Reminga, J. Ora: Organization risk analyzer; DTIC Document: 2004. 